\title{
Design and Analysis of a Clamping Plate for Automobile using Press Tool
}

\author{
Dharshan B G, K C Ananthapadmanabham, Somashekar R
}

\begin{abstract}
The objective of the work is to design and analysis of a press tool for component clamping plate which is used in automobile to meet the production requirement of 2,00, 000 components for an automobile. To achieve this press tool having combination of operations like blanking, piercing and bending is designed for producing a clamping plate in a single stroke in two stages and to optimize production rate and manufacturing cost. Based on features in the component, compound die is designed which can perform blanking and piecing operation in first stage followed by bending operation in the second stage. The structural analysis was carried out for the forming dies and punches which shows that both the deflections and the stresses are well within the limits.
\end{abstract}

Key Words - Clamping Plate, die sets, blanking dies, press tool, piercing punch, forming die and punch.

\section{INTRODUCTION}

Press tools are extensively used for a component which is fabricated in sheet metal may vary from a tiny item in a wrist watch to a large aircraft part with complex shapes. Manually it is very difficult to manufacture sheet metal components which is having complex shapes and having dimensional importance in its applications. Now a day's practice is to produce most of the sheet parts of any shape by using specially designed press tools and other combination of operations. The design of press tools and its manufacturing procedure are highly specialized and knowledge intensive in nature stampings are parts cut and formed from sheet metal. This sheet metal stampings have now replaced many components which were earlier cast or machined. Material economy and the resultant reduction in weight and cost, high productivity, use of unskilled labour and high degree of possible precision have rendered press work indispensable for many mass produced goods, such examples can be found in automobiles, aircraft, house hold articles, electronic and electrical appliances and others. This work covers the design and analysis of a press tool die set for the manufacture of hot rolled sheet component "clamping plate", aimed at high productivity. A new tool with mass productivity and precise component are the primary requirements. To accomplish this through careful examination of the sheet metal component sample (3D solid

Manuscript received on January 27, 2021

Revised Manuscript received on February 22, 2021

Manuscript published on February 28, 2021

Dharshan B.G, Associate Professor in the Department of Mechanical Engineering, Don Bosco Institute of Technology Email:dharsubg@gmail.com

K C Ananthapadmanabham, Associate Professor in the Department of Mechanical Engineering, Don Bosco Institute of Technology Email:kcananth2000@gmail.com

Somashekar R, Assistant Professor Department of Mechanical Engineering, Don Bosco Institute of Technology Email:somashekarr@hotmail.com

\section{METHODOLOGY}

A. Component Details

The component "clamping plate" under consideration is a rectangular component of uniform thickness $1.4 \mathrm{~mm}$ and size $92 \mathrm{~mm} \times 60 \mathrm{~mm}$. The component requires blanking of rectangular piece of size $103 \mathrm{~mm} \times 60 \mathrm{~mm}$, four pierced hole of $\Phi 9 \mathrm{~mm}$ and forming of the sheet to a depth of $10 \mathrm{~mm}$ throughout the width of the component. As per the customer requirement gang stage tool is designed. Isometric view of the component is shown in Figure 1.
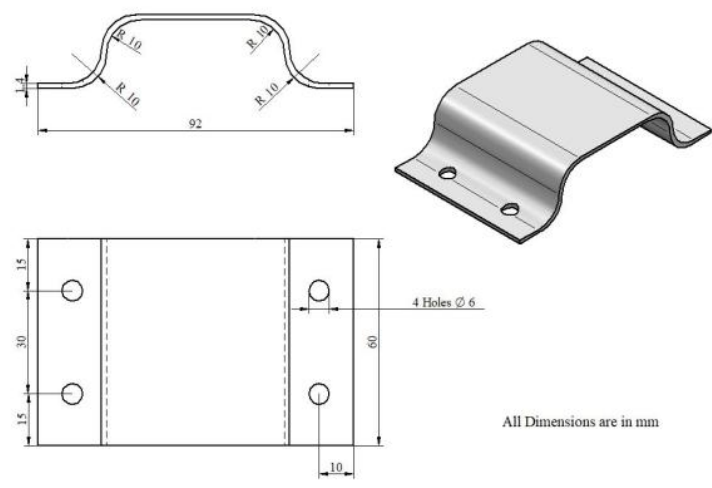

Figure 1. Component drawing

B. Material used in Press Tool

Development and economical operation of the press tool is based on choice of materials. Steels used must be of suitable compositions and produced under best possible mill conditions. Steels play an important role in manufacturing press tools. Because tool life is governed by the steel used, appropriate heat treatment is also an important factor in determining tool strength. Tool materials must satisfy the Structural soundness and uniformity, Good machinability, sufficient strength and hardness to resist deformation in operations, sufficient toughness to resist cleavage and erecting, Wear resistance and resistance to softening effect of heat.

$>$ High carbon high chromium tool steel (HCHCR)

$>$ Oil hardened tool steel (OHNS)

$>$ Water hardened tool steel (case hardened steel)

$>$ Mild steel

C. Die set and Die construction

The die set is one of the basic tools of the stamping industry. It consists of a lower bolster and an upper bolster, together with guide posts and bushings by means of which the bolsters are aligned. The bottom bolster supports the bottom half of the press tool consisting die block, front guide plate, rear guide plate, stripper plate, finger stop etc., They are fastened to the bottom bolster by means of socket head screw and dowels ensures alignment.

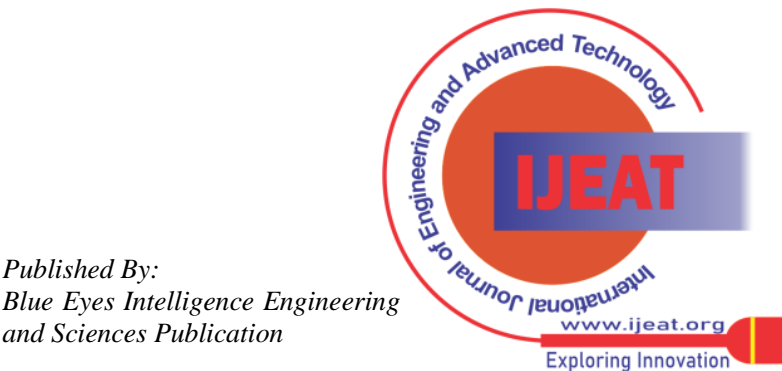




\section{Design and Analysis of a Clamping Plate for Automobile using Press Tool}

The top bolster accommodates punches, punch plate, punch back plate etc. They are fastened by socket head screw and aligned by dowels. The top half and bottom half of the press tool are again aligned by guide pillar and guide bush with a clearance fit $\mathrm{H} 7 / \mathrm{h} 6$. The guide bush OD is having interference fit with top bolster H7/ P6. The exploded view of die set is shown in Figure 2.

TABLE 1. ELEMENTS OF A DIE SET

\begin{tabular}{|l|l|l|l|}
\hline SN & Description & Material & Hardness \\
\hline 1 & Guide pillar & OHNS & HRC 55-57 \\
2 & Guide Bush & OHNS & HRC 55-57 \\
3 & Bottom Bolster & Mild Steel & -- \\
4 & Top Bolster & Mild Steel & -- \\
\hline
\end{tabular}

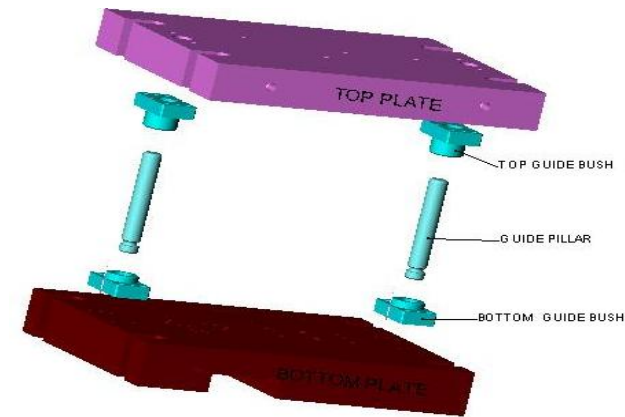

Figure 2. Exploded view of die set

\section{Compound and Forming Dies}

The term Compound die is applied to dies in which two or more cutting operations are performed, typically piercing and blanking are performed in the same single station and completed during the same single press cycle. The action of the piercing punch-die functions must be directionally opposed to the action of the blanking punch die functions. If the piercing punches do not act in the opposite direction with respect to the blanking punch, the die cannot be classified as a compound die.Forming dies, often considered in the same class with bending dies, are classified as tools that form or bend the blank along a curved axis instead of a straight axis. There is very little stretching or compression of the material. The internal movement or the plastic flow of the material is localized and has little or no effect on the total area or thickness of the material. The operations classified as forming are bending, drawing, embossing, curling, beading, twisting, spinning and hole flanging. Compound and forming dies are shown Figure 3 and Press tool in closed condition shown in Figure 4.

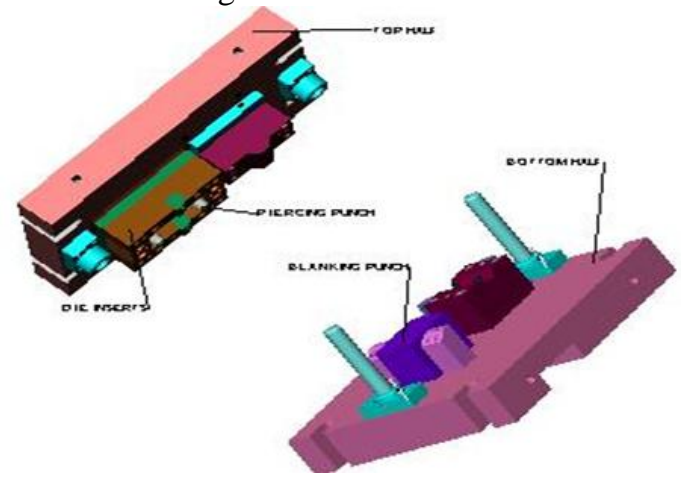

Figure 3. Compound and forming dies

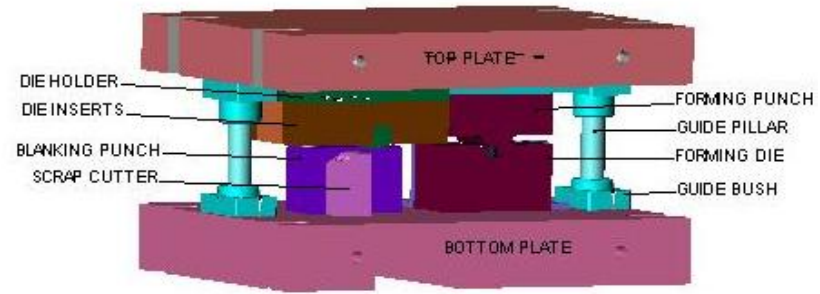

Figure 4. Press tool in closed condition

\section{PRESS TOOL DESIGN}

The component is studied in detail for its size, shape and variation in cross-section. In this section step by step approach to the design of press tools based on experience, empiricism and expertise as applied to "Clamping Plate" and various design calculations are given below:

\section{A. Component details}

Thickness of strip: $\quad 1.4 \mathrm{~mm}$

Material : Hot rolled steel

Type of feed : $\quad$ Manual

Supply Condition: $\quad$ Soft

\section{B. Strip layout and material utilization}

This is forming tool the development length can be calculated using the formulae.

Development length $(\mathrm{DL})=\mathrm{L} 1+\mathrm{BA} 1+\mathrm{L} 2+\mathrm{BA} 2+\mathrm{L} 3$

Bend Allowance $(\mathrm{BA})=\pi \mathrm{A} / 180(\mathrm{IR}+\mathrm{KT})$

Where $A=$ Angle between length (L1) \& length (L2)

$$
\begin{aligned}
& \mathrm{IR}=\text { Internal radius } \\
& \mathrm{K}=\text { Constant }(1 / 3 \text { for } \mathrm{IR}<2 \mathrm{t}) \\
& \mathrm{T}=\text { thickness of strip }
\end{aligned}
$$

Development length $=103 \mathrm{~mm}$

Width of strip = Width of component +2 (thickness) $\times 2$

$$
=60+2(1.4) \times 2
$$$$
=66 \mathrm{~mm}
$$

Length of strip $=$ Length of component +2 (thickness) $\times 2$

$$
=103+2(1.4) \times 2
$$

\begin{tabular}{|c|c|}
\hline & Strip width $\mathrm{x}$ le \\
\hline$=$ & $6180 \times 1 \times 100$ \\
\hline & $66 \times 109$ \\
\hline$=$ & 85.9 \\
\hline
\end{tabular}$$
=109 \mathrm{~mm}
$$

$\%$ material utilization $=$ Area of blank $\mathrm{x}$ number of rows $\mathrm{x}$ 100

C. Clearance between punch and die

The clearance between punch and die for effective shearing is calculated by formulae

$$
\begin{aligned}
\mathrm{C} & =0.005 \times \mathrm{t} \times 3 \sqrt{\mathrm{Fs}} \\
& =0.005 \times 1.4 \times 3 \sqrt{ } 28 \\
& =0.03 \mathrm{~mm} / \mathrm{side}
\end{aligned}
$$

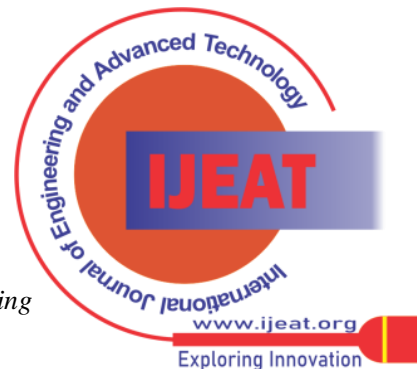




\section{Design and Analysis of a Clamping Plate for Automobile using Press Tool}

\section{Calculation of total Shear force}

\begin{tabular}{|c|c|c|}
\hline Shear Force & $=$ & Shear Area x shear stress \\
\hline FS & $=$ & (Length of cut $\mathrm{x}$ thickness) $\mathrm{x}$ \\
\hline \multicolumn{3}{|l|}{ Shear stress } \\
\hline FS & $=$ & L $x \mathrm{t} \times \mathrm{fS} \times \mathrm{n}$ \\
\hline Where FS & $=$ & Shear force in $\mathrm{Kgf}$ \\
\hline $\mathrm{L}$ & $=$ & Length of cut in mm \\
\hline $\mathrm{t}$ & $=$ & Thickness of component in $\mathrm{mm}$ \\
\hline fS & $=$ & Shear stress in $\mathrm{Kg} / \mathrm{mm} 2$ \\
\hline $\mathrm{n}$ & $=$ & Number of holes \\
\hline
\end{tabular}

i) Force for piercing two holes $(\phi 9 \mathrm{~mm})$

$\begin{array}{rlrl}\text { FSh1 } & = & & \pi \mathrm{dt} \times \mathrm{fS} \times \mathrm{n} \\ & = & \pi \times 9 \times 1.4 \times 30 \times 2 \\ & = & 2373.8 \mathrm{Kgf}\end{array}$

ii) Force for blanking

$$
\pi \times 9 \times 1.4 \times 30 \times 2
$$

FSh2 =

$\mathrm{L} \times \mathrm{t} \times \mathrm{fS}$

$=\quad 2(103+60) \times 1.4 \times 28$

$=\quad 12779 \mathrm{Kgf}$

iii) Force for forming

$\mathrm{FSh} 3=$

\section{$1.2 \mathrm{SU} \times \mathrm{w} \times \mathrm{t} 2$}

\section{$\mathrm{L}$}

$\mathrm{kg} / \mathrm{mm} 2$

SU $\quad=$

ultimate

tensile strength in

$\begin{array}{ll}\mathrm{W} & = \\ \mathrm{t} & = \\ 1 & =\end{array}$

width of forming in $\mathrm{mm}$

thickness of component in $\mathrm{mm}$

forming span

FSh3 =
13

Total force

$$
=\quad 199.3 \mathrm{Kgf}
$$

$$
\begin{aligned}
& =\text { FSh } 1+\text { FSh2 +FSh3 } \\
& =2373.8+12779+199.3 \\
& =15352.1 \mathrm{Kgf}
\end{aligned}
$$

\section{E. Press Capacity Selection}

The press should be capable of delivering approximately $30 \%$ greater than total shear force required by tool

$\therefore$ Press capacity required $=$

Total shear force x 100

$\begin{array}{lr}= & 15352.1 \times 1 \\ = & \\ & \\ & \\ 3 & \sqrt{ } \text { Total shear force } \\ 3 \sqrt{ } 30 \\ 32 \mathrm{~mm}\end{array}$

Thickness of die block should be more to accommodate the shut height of the tool; hence thickness of the die block is taken as $45 \mathrm{~mm}$

ii) Width of die block = Strip width +2 (thickness of die block)

$$
\begin{aligned}
& =60+2(36) \\
& =132 \mathrm{~mm}
\end{aligned}
$$

iii) Length of die block $=$ Strip length +2 (thickness of die block)

$$
\begin{aligned}
& =103+2(36) \\
& =175 \mathrm{~mm}
\end{aligned}
$$

Die Block dimensions $=45 \times 132 \times 175 \mathrm{~mm}$
Corresponding to the standard die block, Standard die set is selected from centre pillar die set.

\section{G. Design of piercing punch}

Pierced hole is internal feature of component. Piercing punch controls the size and clearance is applied to die. Therefore,
a) Punch diameter

$$
=9 \mathrm{~mm}
$$
b) Die aperture for $\phi 9 \mathrm{~m}$ hole$$
=9+2 \times 0.03
$$$$
=9.06 \mathrm{~mm}
$$

c) Punch Length

$=$ Shut height - Die thickness Sum of die set -Bolster

thickness -

$$
\begin{aligned}
& \text { Punch plate thickness } \\
= & 262-70-132-6 \\
= & 56 \mathrm{~mm}
\end{aligned}
$$

\section{H. Design of Blanking Punch}

In Blanking operation, die controls the size and clearance is applied to punch.
a) Length of the punch =
Length of punch $-2 \mathrm{C}$
b) Width of the punch
$\begin{array}{ll}= & 103-2 \times 0.03 \\ = & 102.94 \mathrm{~mm} \\ = & \text { Width of punch }\end{array}$
$-2 \mathrm{C}$
$\begin{array}{ll}= & 60-2 \times 0.03 \\ = & 59.94 \mathrm{~mm}\end{array}$

\section{Design of Forming Punch and Forming Die}

While designing forming punch and forming die the gap between punch and die is $t+10 \% t$ is taken. This $10 \%$ of $t$ is provided to accommodate the variation in thickness of the component so that it does not damage the component.

i) Forming punch

Thickness of forming punch $\quad=$ Shut height - Die thickness -

thickness Sum of Die Set -Bolster

$$
\begin{aligned}
& =262-70-132-15 \\
& =45 \mathrm{~mm}
\end{aligned}
$$

- Punch plate thickness

Length of the forming punch $=123 \mathrm{~mm}$

Width of the forming punch $=70 \mathrm{~mm}$

ii) Forming die

Thickness of forming die $=$ Shut height - punch thickness sum of die set - Bolster thickness - forming punch thickness

$$
\begin{array}{ll}
= & 262-47-132-15 \\
= & 68 \mathrm{~mm}
\end{array}
$$

Length of forming die $=123 \mathrm{~mm}$

Width of forming die $=70 \mathrm{~mm}$

\section{J. Land and Draft}

Land: After few thousand of operations the cutting edges of punch as well as the die block aperture becomes blunt, this results in burr on the component, hence die block surface are grinded by about $0.2 \mathrm{~mm}$ to get the sharp cutting edges.A land of 3 to $5 \mathrm{~mm}$ is recommended for the die block.

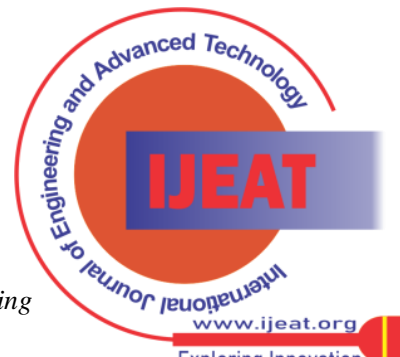




\section{Design and Analysis of a Clamping Plate for Automobile using Press Tool}

Draft: The Sheared press components in die block apply horizontal force on the die block and do not fall freely. The amount of horizontal force applied per shear pieces that are stacked in die block is about $10 \%$ of the shear force. The slender punches like small piercing punches, notching punches and other delicate punches break causing tool lay down. Therefore, $1 / 4^{\circ}$ to $1 / 2^{\circ}$ draft is provided for the entire shearing aperture.

\section{ANALYSIS}

In the formation of nearly any engineering design project, some type of analysis is required. Probably the most powerful analysis feature of a CAD system is the finite element method. With this technique, the object is divided into a large number of finite elements which form an interconnecting network of concentrated nodes. The analysis may involve stress-strain calculation or any dynamic behaviour of the system being designed. The computer can be used to aid in this analysis work. By using a computer with significant computational capabilities, the entire object can be analysed for stress-strain and other characteristics by calculating the behaviour of each node.. The output of the finite element analysis is often best presented by the system for easy visualization by the user. By determining the interrelating behaviour of all the nodes in the system, the behaviour of the entire object can be assured For example, in stress - strain analysis of an object, the output may be shown in the form of a deflected shape superimposed over the unstressed object.

$\checkmark$ A typical analysis has three distinct steps.

$\checkmark$ Build the model

$\checkmark$ Apply loads and obtain the solutions

$\checkmark \quad$ Review the results.

ANSYS uses pre-processor to define the element type to be used, the element real constants, the material property and to create the model geometry.CAD model and corresponding meshing of Forming die and punch are shown in Figure 5 through Figure 8
Figure 5. Forming Die

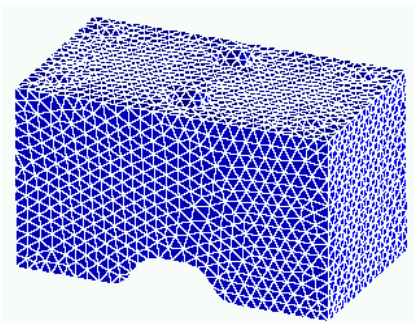

Figure 7. Meshed model of Forming Die

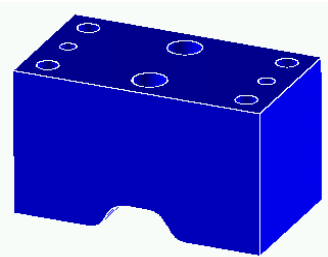

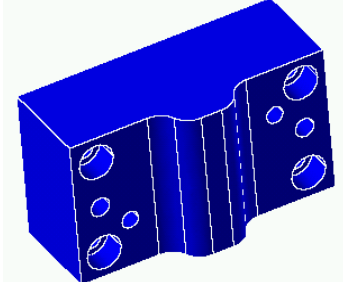

Figure 6. Forming Punch

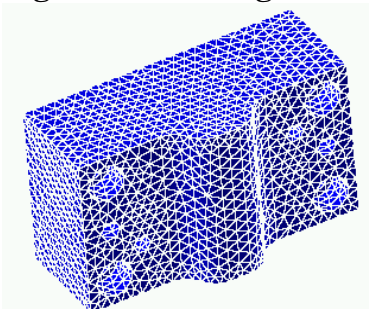

Figure 8. Meshed model of Forming Punch
B. Loading and solution

The word load in ANSYS terminology includes the boundary condition and the externally or internally applied force functions. Loads are divided into six categories like DOF constraints, force loads, surface loads, Inertia loads, and coupled filed loads. The main goal of the finite element analysis is to examine how the structure response to the loading condition, specifying the proper loading condition, is therefore, key step to the analysis. In the solution phase of the analysis, the computer takes over and solves the simultaneous equations that the finite element method generates. The results of the solutions are:

1. Nodal degree of freedom values, which forms the primary solution.

2. The derived values, which forms the element solution. The element solution is usually calculated by elements integration points.

\section{Review of results}

Stress analysis is the most important step in finite element analysis. Two post processors are available to review the results. Post processor-1allows reviewing the results over the entire structure at any load step. Post processor-2 allows reviewing the variation of the particular result item at the specific point in the model with respect to the time, frequency or some other result item. Structural Analysis for forming die and forming punch are carried out for determining the deflections and stresses. Figure 9 and 10 shows the deformation in forming die and punch. Figure 11 and 12 shows the von misses stresses in forming die and punch. It was found that stresses were within the limits.

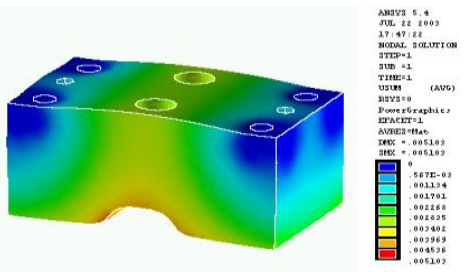

Figure 9. Deformation of Forming Die

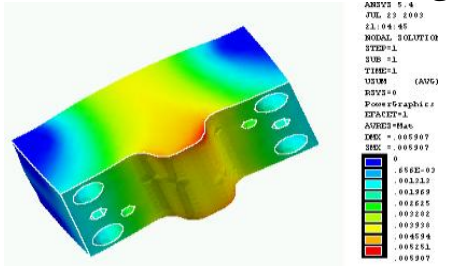

Figure 10. Deformation of Forming Punch

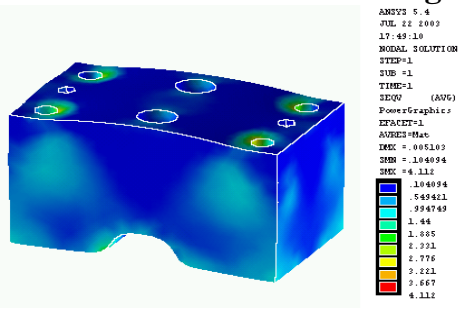

Figure 11.Von misses Stresses in Forming Die

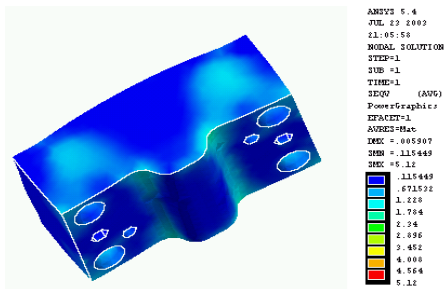

Figure 12. Von misses Stresses in Forming Punch

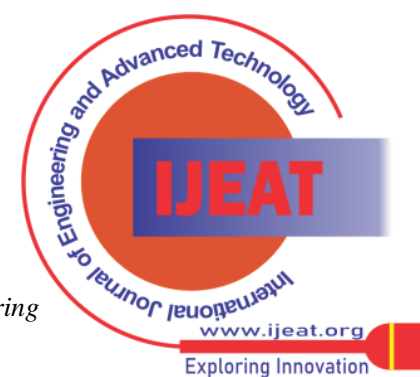




\section{Design and Analysis of a Clamping Plate for Automobile using Press Tool}

\section{CONCLUSIONS}

Design and analysis of press tool for hot rolled steel component of clamping plate has been carried out in this work. Several important criteria in the design of compound press tool and to manufacture the various elements like dies and punches based upon critical examination of the geometry of the component is done. To optimize production rate and manufacturing costs compound tool is been designed. This will make the die set compact and the force required to carry out blanking and piercing will be minimum. By using bending dies, forming operations are carried out in the second stage. Therefore in single stroke with two stages blanking, piercing and bending operations are accomplished. This will make the die cost effective and less susceptible to burr formation. The structural analysis on form punch and dies gives deflection $0.004 \mathrm{~mm}$ and stresses $5.68 \mathrm{~kg} / \mathrm{mm}^{2}$

\section{ACKNOWLEDGMENT}

The authors express their thanks to HOD and staff of Mechanical Engineering Department, to the Principal of DBIT and to the Management of Wayanamac Education Trust, Bangalore, for the support and encouragement during this design and analysis of injection mold tool.

\section{REFERENCES}

1. JR Paquin, R E Crowley, “ Die Design Fundamentals “, industria Press Inc., 1996

2. Fank W Wilson, Philip D Harvey, ” Die Design Handbook “, McGraw Hill, 1991

3. Eugene Ostergaard, “ Basic Die Making “, McGraw Hill, 1986

4. Dr.JohnG.Nee, “ Fundamentals Of Tool Design ", Society of Manufacturing Engineers, Fourth Edition, 1998

5. Prakash H. Joshi, “ Press tools Design \& Constructions ", Wheeler Publishing, 1999

6. Ismail H S; Chen S T; Hun KKB , " Feature based design of progressive press tool ",2000

7. Wang F; Chang L, "Determination of the bending sequence in the progressive die design “, 1996.

8. David A Smith, " Fundamentals of Press working ", Society of Manufacturing Engg,1999

9. Konnerth U, "A Hydraulic high speedtryout press for the simulation of Mechanical forming processes", Journal of Metal processing Technology, April-2001

10. [10]Prof.K.D.Kattimani, ,Design and analysis of progressive tool for moving contact holder"e. JETIR (ISSN-2349-5162)

11. [11]B. A. Dherange, „Design and Finite Element Analysis of Guide Pillar for Compound Press Toole. International Journal of Advance Research in Engineering, Science \& Technology (IJAREST), Volume 2, Issue 7, July- 2015.

12. Vishwanath M.C., „Design of Progressive Draw Tool ${ }^{\text {ee }}$. International Journal of Scientific and Research Publications, Volume 3, Issue 8 , August 2013, ISSN 2250-3153

13. "Development of a Sheet-Metal Component with a Forming Die Using CAE Software Tools (Hyper form) For Design Validation and Improvement" by Amit D. Madake International Journal of Modern Engineering Research (IJMER) (2013)

14. Nilesh N. Patill "Overview of Press Tool Design used for Sheet Meta Processes with Design Considerations". International Journal of Science and Research (IJSR) ISSN (Online): 2319-7064 Index Copernicus Value (2013): 6.14 | Impact Factor (2013): 4.438

15. R. S. Mhetre, R. J .Dhake, "Using Failure Mode Effect Analysis in Precision Sheet Metal Parts Manufacturing Company". Research, Vol. 1, No. 2, 2012

16. J.R. Cho, S.J. Moon, Y.H. Moon, S.S. Kang Finite element investigation on spring-back characteristics in sheet metal U-bending process Journal of Materials Processing Technology 141 (2003) 109116

17. PusitMitsomwang, Shigeru Nagasawa Effects of shearing parameter on cutting characteristics of polycarbonate sheet subjected to straight punch/die shearing.
18. K. DilipKuman, K. K. Appu kuttan, V.L. Neelakantha, Padmayya S Naik Experimental determination of spring back and thinning effect of aluminum sheet metal during L-bending operation Materials and Design

19. SutasnThipprakmasWiriyakornPhanitwongProcess parameter design of spring-back and spring-go in V-bending process using Taguchi technique Materials and Design

20. Cheng Hua Wang, David a. Bourne "Design and Manufacturing of Sheet Metal Parts: Using Features to Aid Process Planning and Resolve Manufacturability Problems"

21. Pawan Kumar Rai, Dr. Aas Mohammad, HasanZakir Jafri, “Causes \& Preventation of Defects (Burr) In Sheet Metal Component"

22. K. Dilip Kumar, K.K. Appukuttan, V.L. Neelakantha, Padmayya S NaikExperimental determination of spring back and thinning effect of aluminum sheet metal during L-bending operation

\section{AUTHORS PROFILE}

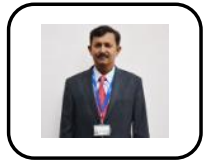

Dharshan B.G working as Associate Professor in the Department of Mechanical Engineering, Don Bosco Institute of Technology with 16 years of Teaching and 5 years of Industrial Experience. Presently author is pursuing research in the area of Polymer Matrix Nan composites. The author has published two journal papers, three papers in international conference and two papers in national conference, life member of ISTE. Email:dharsubg@gmail.com

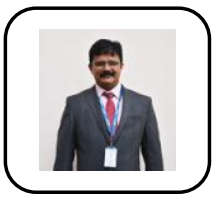

K C Ananthapadmanabham working as Associate Professor in the Department of Mechanical Engineering, Don Bosco Institute of Technology with 22 years of Teaching and 3years of Industrial Experience. The author has submitted Thessis to VTU, Belgaum. The author has published two journal papers, four papers in international conference and four papers in national conference, life member of ISTE. Email:kcananth2000@gmail.com

Somashekar $\mathbf{R}$ working as Assistant Professor in the Department of Mechanical Engineering, Don Bosco Institute of Technology with 10 years of Teaching and 4 years of Industrial Experience. The author has published two journal papers, three papers in international conference and one papers in national conference, life member of ISTE Email:somashekarr@hotmail.com 